\title{
Pharmacological Targeting of BET Bromodomain Proteins in Acute Myeloid Leukemia and Malignant Lymphomas: From Molecular Characterization to Clinical Applications
}

\author{
Diana Reyes-Garau ${ }^{1,+}{ }^{\text {, Marcelo L. Ribeiro }}{ }^{1,2,+}$ (D) and Gaël Roué 1,*(D) \\ 1 Laboratory of Experimental Hematology, Department of Hematology, Vall d'Hebron Institute of \\ Oncology (VHIO), Vall d'Hebron University Hospital, Autonomous University of Barcelona, 08035 \\ Barcelona, Spain; dreyes@vhio.net (D.R.-G.); mlribeiro@vhio.net (M.L.R.) \\ 2 Laboratory of Immunopharmacology and Molecular Biology, Sao Francisco University Medical School, \\ Braganca Paulista, São Paulo 12916-900, Brazil \\ * Correspondence: groue@vhebron.net; Tel.: +34-93-489-3000 (ext. 6402) \\ + These authors contributed equally to the research.
}

Received: 30 July 2019; Accepted: 30 September 2019; Published: 2 October 2019

check for updates

\begin{abstract}
Alterations in protein-protein and DNA-protein interactions and abnormal chromatin remodeling are a major cause of uncontrolled gene transcription and constitutive activation of critical signaling pathways in cancer cells. Multiple epigenetic regulators are known to be deregulated in several hematologic neoplasms, by somatic mutation, amplification, or deletion, allowing the identification of specific epigenetic signatures, but at the same time providing new therapeutic opportunities. While these vulnerabilities have been traditionally addressed by hypomethylating agents or histone deacetylase inhibitors, pharmacological targeting of bromodomain-containing proteins has recently emerged as a promising approach in a number of lymphoid and myeloid malignancies. Indeed, preclinical and clinical studies highlight the relevance of targeting the bromodomain and extra-terminal (BET) family as an efficient strategy of target transcription irrespective of the presence of epigenetic mutations. Here we will summarize the main advances achieved in the last decade regarding the preclinical and clinical evaluation of BET bromodomain inhibitors in hematologic cancers, either as monotherapies or in combinations with standard and/or experimental agents. A mention will finally be given to the new concept of the protein degrader, and the perspective it holds for the design of bromodomain-based therapies.
\end{abstract}

Keywords: bromodomain and extra-terminal domain; BRD2; BRD4; super-enhancer; NF-кB; MYC; combination therapy; hematological malignancies; protein degraders

\section{Introduction}

In eukaryotic cells, acetylation of histone lysine is considered to be the most active protein post-translational modification. Mechanistically, the acetylation impacts the transcription through the neutralization of the positive charge of lysine to disrupt electrostatic interactions between histones and DNA, which leads to a transcriptionally active open state of chromatin [1]. The lysine acetylation is regulated mainly by three classes of proteins, the "writers" (histone acetyltransferases and histone methyltransferase), the "readers" (bromodomain (BRD)-containing) proteins, and the "erasers" (histone deacetylases and histone demethylases) [2-7]. 
Structurally, BRD consist of a left-handed bundle of four alpha helices, with interhelical loops forming a hydrophobic binding pocket that participates in acetyl-lysine identification [4]. In the human genome, the acetyl-lysine-binding BRD are observed over 46 distinct proteins [4,8]. The BRD proteins include, among others, chromatin-modifying enzymes, methyltransferases, helicases, chromatin remodelers, transcriptional co-activators and mediators, and the bromodomain and extraterminal domain-containing (BET) protein family [8]. It is well known that BRD can bind to transcriptional sites and regulate the activity of chromatin remodeling complexes, controlling a wide range of cellular events [2]. BRD-containing proteins are also engaged in the regulation of several signaling cascades, and could be activated upon oncogenic rearrangements, granting them with a key function in the development/progression of several types of cancer, including hematological malignancies. Among these factors, BET proteins represent a novel class of epigenetic readers with the ability to bind acetylated lysine residues in histone and nonhistone proteins, conferring them the capacity to control whole genome activity. The relevance of these proteins in the transcriptional control of malignant hematopoiesis makes pharmacological inhibition of BET protein activity particularly relevant to address the vulnerability of hematological cancers to BRD inhibitors [9]. Accordingly, the idea to target BRD has generated a great interest and culminated in the development of bromodomain inhibitors in a wide range of entities, including acute leukemia, multiple myeloma (MM), and aggressive B-cell lymphoma [2].

\section{The BET Protein Family}

The BET family comprises four members, namely, BRD2, BRD3, BRD4, and the germ cell-specific BRDT, which act as regulators of RNA transcription and cell cycle progression through the activation of RNA polymerase II ( $\mathrm{Pol}$ II). A universal feature of these proteins is the presence of two conserved $\mathrm{N}$-terminal bromodomains (BD1 and BD2) that specifically recognize and bind to acetylated lysine residues on histone tails and other nuclear proteins [4].

Among the BET proteins, BRD2 was the first characterized as a nuclear noncanonical protein kinase with a role in the transduction of mitogenic signal [10,11]. BRD2 binds to acetylated $\mathrm{H} 3$ and $\mathrm{H} 4$ histones, recruits transcription factors, transcriptional co-activators, and transcriptional co-repressors, activating the transcription [12-14]. According to Denis et al. [14], the transcription complexes containing BRD2 and the chromatin remodeling machines are (i) TATA binding factor-associated factors and Pol II, (ii) activated transcription factors E2F and DP-1, (iii) Mediator proteins, (iv) chromatin/histone modification enzymes (HDAC11, CBP, and p300), and (v) SWI/SNF remodeling complex components. Together with BRD3, these complexes are needed for a permissive Pol II transcription through acetylated nucleosomes [15]. Initially, it has been demonstrated that BRD2 regulates cell cycle through the recruitment of E2F1 and E2F2, which are key transcriptional regulators of $S$ phase genes $[10,14,16]$. Together with the fact that BRD2 is physically present at the CCNA promoter at both the G1 and $\mathrm{S}$ phases of the cell cycle, these data confirm both the role of BRD2 as a scaffold that mediates access of transcriptional control proteins to chromatin, and the functional link between BRD2 and proliferation [16].

\section{BRD4: Biological Roles and Molecular Mechanisms of Action}

The best known member of BET family is BRD4, which shares $80 \%$ identity at the amino acid level with BRD2 [17]. BDR4 is a transcriptional and epigenetic regulator that has a crucial role during embryogenesis, controlling cell cycles and maintaining genome stability. The role of BRD4 as a transcriptional regulator was initially proposed due to its interaction with both (i) cyclin T1 and CDK9 which belong to the active form of positive transcription elongation factor $b$ (P-TEFb), and (ii) Mediator complex, a 30 subunit coactivator complex that physically interacts with BRD4 and $\mathrm{P}-\mathrm{TEFb}[18,19]$. Additionally, Mediator and BRD4 stabilize each other's occupancy over the genome, and both cooperate in recruiting P-TEFb [19-21]. The first attempt to characterize BRD4 identified it as a protein associated with G1-S cell cycle progression [22]. Mechanistically, it has been shown that 
BRD4 is recruited to the promoters of G1 genes where it binds to acetylated histones using both BRD modules. The BD2 domain identifies and interacts with cyclin T1, which is particularly important to maintain Pol II in the promoter region of active genes, leading to transcription initiation and elongation of a large set of genes related to cell growth, including MYC and its target genes [23-26]. ChIP-seq data have shown that BRD4 co-localizes at the nucleosome-free site occupied by transcription factors (TFs) at enhancers and promoters $[27,28]$. Furthermore, it was demonstrated that BRD4 also forms super enhancer complexes with the Mediator complex, favoring the association of transcription regulating proteins, regulating then the expression of some oncogenic drivers in a large set of cancers [29].

Beside these functions, BRD4 also has an important role in mediating inflammatory transcriptional cascades by interacting with acetylated nuclear factor kappa B (NF- $\mathrm{B}$ ) subunit RELA (also known as p65). Upon stimulation, RELA is acetylated at lysine 310 through the p300/CBP coactivators, which maximizes the transcriptional activation of NF-кB [30]. Subsequently, Huang et al. showed that acetylated RELA activates NF- $\mathrm{kB}$ through the recruitment of BRD4 via specific interaction between the acetylated lysine-310-BRD4 bromodomains. BRD4, then activates CDK9, which phosphorylates PolII, thus promoting NF-KB transcriptional signaling [31]. In parallel, BRD4 plays a structural role supporting the higher chromatin architecture [32]. Subsequently, Devaiah et al. showed that BRD4 can act as a histone acetyltransferase by acetylating H3K122 residue, leading to nucleosome destabilization and clearance accompanied by chromatin decompaction. Thus, an upregulation of BRD4 might lead to chromatin remodeling, followed by reduced nucleosome occupancy and increased gene transcription [33] (Figure 1). Beside its pivotal role in controlling cell cycles, BDR4 is also committed with nonhomologous end-joining (NHEJ) DNA repair [34,35]. In B lymphocyte biology, it has been reported that BDR4 is required during immunoglobulin isotype switching for the accomplishment of class switch recombination after DNA double strand breaks (DSBs) by Activation Induced cytidine Deaminase (AID) [34]. It is known that DNA DSBs are followed by $\mathrm{H} 4$ acetylation and $\gamma \mathrm{H} 2 \mathrm{AX}$, which induces BRD4 recruitment. Amongst many DNA repair players that interact with BRD4, 53BP1 is its major binding partner in DNA damage regulation. The interplay of BRD4 at DSBs maintains the binding of 53BP1 with DNA repair complexes on site, promoting the NHEJ activity [34,35]. In addition, BRD4 has been also involved with the activation of DNA damage checkpoint signaling in a transcriptionally independent manner. In this sense, BRD4 interacts and regulates the function of pre-replication factor CDC6, which is essential for the activation of replication checkpoint response [36]. Recently, it has been highlighted that BRD4 has a nontranscriptional role controlling telomere homeostasis. Both the treatment with BET inhibitors and BRD4 knock-down lead to the downregulation of telomerase reverse transcriptase (TERT) and an impairment of telomerase activity, followed by a decrease in the recruitment of histone active marks [37]. Similarly, Wang et al. showed that a long-term treatment of mouse and human cells with BDR4 inhibitors led to a telomere reduction, however without affecting the telomerase enzymatic activity [38]. Although BRD4 has an important role in telomere maintenance, the mechanism(s) by which it occurs is not fully understood. It has been hypothesized that BRD4 might serve as a platform, recruiting and stabilizing the binding of the telomerase complex, leading to telomeres lengthening [29]. 


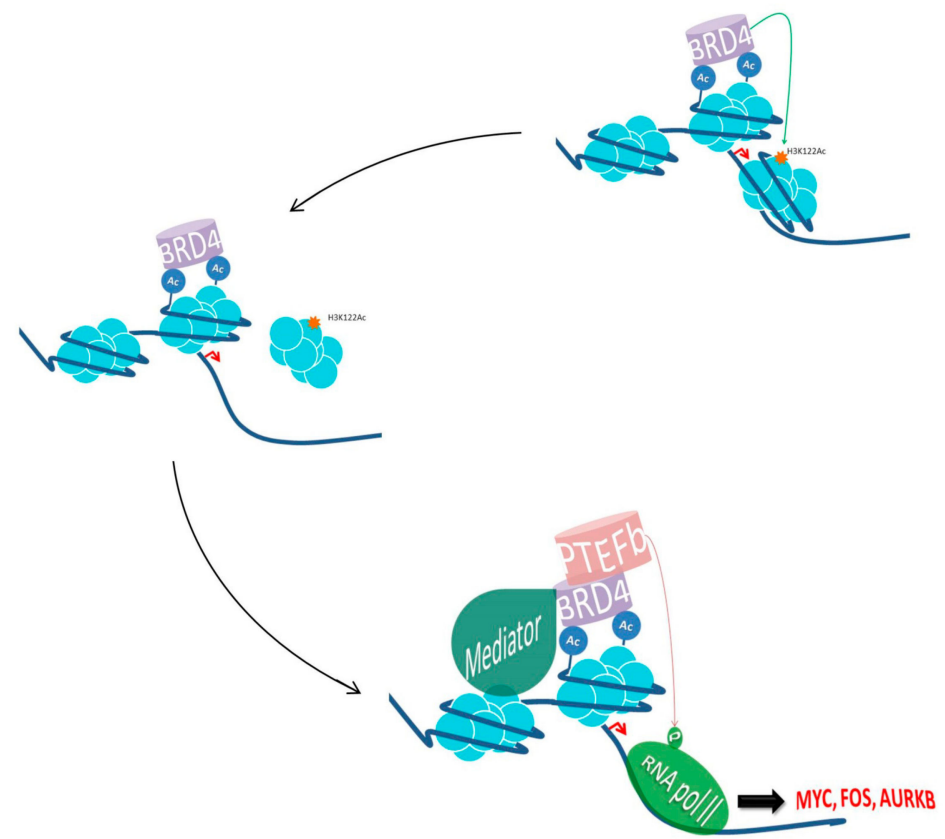

Figure 1. Schematic representation of BRD4 transcriptional activation. BRD4 acetylates histone tail lysines (Ac), and eventually H3K122, leading to nucleosome clearance and the recruitment of Mediator complex favoring and stabilizing the binding of RNA-PolII. BRD4 also interacts and activates P-TEFb, stimulating RNA-PolII to promote transcriptional activation of factors involved in cell cycle control and proliferation such as Aurora B, Cyclin D, E2F, MYC, FOSL1, TCF4 and Wnt5a.

\section{The Role of BET Proteins in Hematological Cancers}

As mentioned previously, the BET family of proteins are important epigenetic regulators involved in promoting gene expression of critical oncogenes by keeping an abnormal chromatin state in various hematologic malignancies, including MM, acute myelogenous leukemia (AML), acute lymphoblastic leukemia (ALL), diffuse large B-cell lymphoma (DLBCL), Burkitt lymphoma (BL), and mantle cell lymphoma (MCL) [39-42]. Among the oncogenes known to be regulated by BET proteins in these diseases, MYC is probably the most relevant, as it is overexpressed in about $60 \%-70 \%$ of all cancers [43].

\subsection{MYC-Driven Mechanisms of Oncogenesis Regulated by BET Proteins}

Mechanistically, MYC accumulates into promoter regions acting as a transcriptional amplifier overreacting gene expression profile [44]. MYC recruitment increases in histone lysine acetylation sites which is associated with transcriptional activation [45]. This oncogene also enhances transcription elongation through the recruitment of P-TEFb and the Mediator complex $[25,46]$.

In hematopoietic malignancies, BRD4 was found to exert a wide role in keeping MYC stable expression, providing a rationale for the use of BET inhibitors for the targeting MYC-dependent transcription [39,41,42]. In B-cell lymphomas it has been reported that chromosomal translocations involving MYC locus are common to germinal center B-cell (GCB) DLBCL, with about $32 \%$ of DLBCL patients harboring MYC overexpression [47]. Likewise, BL is also characterized by translocations involving the fusion of an immunoglobulin heavy- or light-chain gene promoter to MYC locus, which leads to MYC expression in the B-cell compartment and consequent lymphomagenesis [48]. Given the relevance of MYC in DLBCL and BL, BET inhibitors are currently being tested in clinics (see below). Additionally, it has been observed that BRD4 also plays a crucial role in AML maintenance through MYC activation and aberrant transcriptional elongation, the suppression of BRD4 being a major cause of cell-cycle arrest and apoptosis induction [39]. 


\subsection{BET-Mediated Expression Regulation of Other Oncogenes}

In addition to MYC, BRD4 also regulates the expression of several regulators of the cell cycle, including CDK4/6 and cyclin D1 $[49,50]$. These findings are particularly relevant in MCL, as this entity is characterized by the $t(11 ; 14)$ translocation that fuses the CCND1 gene, coding for cyclin D1, to the immunoglobulin heavy locus gene, leading to the overexpression of the cyclin, thus increasing CDK4/6 activity with the consequent deregulation of the cell cycle at the G1 to S transition [51].

Another relevant driver gene interacting with bromodomain proteins is nucleophosmin (NPM1). Epidemiological data have shown that about $35 \%$ of AML cases harbor NPM1 mutation, this alteration being one of the most common distinctions in AML [52]. Different functions have been attributed to NPM1, which include (i) ribosomal assembly, as a nucleolar histone chaperone, and (ii) the regulation of the ARF-p53 pathway [52]. Such a role depends on drive back and forth between the nucleus and cytoplasm. Functionally, NPM1 interacts with BRD4 in the nucleus and HEXIM1 represses BRD4-mediated transcriptional elongation [53]. So, considering that the NPM1 loss of function mutation leads to a cytoplasmic localization of the NPM1 [54], transcriptional repression of BRD4 by NPM1 is impaired, leading an increased expression of MYC and BCL2 [53]. Recently, BRD4 has also been described as an important regulator of AML cell autophagy through distinct complementary mechanisms including (i) a direct modulation of autophagy-related genes, and (ii) an indirect increase of reactive oxygen species release by KEAP1 (kelch like ECH associated protein 1), followed by a blockade of the NRF2 (nuclear factor, erythroid 2 like 2) antioxidant pathway [55].

Chromosomal translocations involving the lysine methyltransferase $2 A(K M T 2 A)$ gene occur in AML patients, being rare in adults (5\% of cases) and more common in children (22\% of cases) [56]. This phenomenon is also observed in approximately $10 \%$ of ALL cases [57]. KMT2A encodes for a histone methyltransferase involved in transcriptional regulation [57,58]. KMT2A translocation leads to a fusion of KMT2A with different regulators of transcriptional elongation such as the super elongation complex (SEC), which leads to a deregulated transcription driving leukemogenesis. BRD3 and BRD4 are components of the SEC and the polymerase-associated factor complex, which plays a role in KMT2A localization and transcription [59]. Hence, NPM1-mutated AML cases, as well as patients harboring translocations involving KMT2A gene, represent a suitable target population for BET inhibitor (BETi) therapy.

\section{Characterization and Evaluation of BET Inhibitors}

\subsection{Preclinical Activity of BET Inhibitors as Monotherapies in Hematological Malignancies}

Small molecules capable of disrupting the BET protein's interaction with acetylated histones were first characterized from chemical compounds targeting the acetyl lysine binding pocket of the histone acetyltransferase $\mathrm{p} 300 / \mathrm{CREB}$-binding protein (CBP), thus preventing its association with the tumor suppressor protein p53 during CDKN1A transcription in response to DNA damage. These molecules were found by nuclear magnetic resonance (NMR) spectroscopy screening from a library of compounds selected according to their capacity to disrupt this specific protein-protein association [60].

Subsequently, several BET inhibitors with an improved affinity for the BRDs have been developed and tested in experimental studies in order to get distinct therapeutic approaches for the treatment of a wide range of malignancies. Among these molecules, the thieno-triazolo-1,4-diazepine JQ1 is a competitive interactor of the BRD2 and BRD4 acetyl-lysine binding motifs [42,61]. The antiproliferative activity of this compound was first characterized in a panel of human leukemia and lymphoma cell lines, achieving a 50\% inhibition of cell proliferation in almost all the cell lines tested, at concentrations ranging between $50 \mathrm{nM}$ and $500 \mathrm{nM}$ [42]. Mechanistically, this compound was described to downregulate MYC expression by promoting BRD2 and BRD4 displacement from MYC promoter region in both human lymphoma and T-ALL cell lines [42,62], as well as in mouse models of MM [41]. JQ1 was also described to directly target BRD4-Nuclear Protein in Testis (NUT) oncoprotein interaction [63]. This property grants the drug with the capacity to abrogate cell proliferation in vitro and to inhibit tumor growth in 
mice xenografted with a panel of cell lines bearing different BRD4-NUT translocations, thus suggesting a therapeutic potential for the treatment of NUT midline carcinoma (NMC) [61].

These promising results led to the design and development of other BET inhibitors structurally related to JQ1. Among them, CPI203 showed an improved bioavailability when compared to its precursor $[64,65]$ together with a remarkable antitumoral activity in different preclinical models of B-cell non-Hodgkin lymphomas (B-NHLs), including MCL [66], DLBCL [67,68], MM [69], and MYC+/BCL2+ double hit lymphoma [70]. Originated from the same company, the benzoisoxazoloazepine CPI0610 was assessed in in vivo studies in mice, where its tumor reducing activity appeared to correlate with a BET-driven reduction in MYC gene expression. Moreover, CPI0610 treatment also impaired the production of pro-inflammatory cytokines through its action over the NF- $\mathrm{B}$ pathway [71], and the compound displayed potent cytotoxicity against MM cell lines and primary cultures xenografted in mice by triggering $\mathrm{G}_{1}$ cell cycle arrest and caspase-dependent apoptosis, even in the presence of protective stroma [72].

Later on, two other BET inhibitors were developed by Gilead Sciences Inc., namely GS-5829 and GS-626510, which demonstrated a good capacity to bind reversibly BRD2, BRD3, and BRD4 BET proteins, thus preventing the recruitment of these latest to acetylated histones [73]. GS-626510 has also been shown to regulate the production of a set of cytokines when combined with the PI3K $\delta$ inhibitor, idelalisib, in cocultures involving M2-polarized macrophages and DLBCL primary samples [74].

The thienotriazolodiazepine compound MK-8628/OTX015 (birabresib) has also been demonstrated to efficiently prevent the binding of BRD2, BRD3, and BRD4 to acetylated histone H4. Several works have pointed out its capacity to promote cell cycle arrest, together with the downregulation of MYC, BRD2, and BRD4 protein levels and upregulation of the PolII negative transcription regulator, HEXIM1, in human AML and ALL cell lines and primary samples [75]. Additionally, this compound has been reported to induce apoptosis in non-GCB subtypes of DLBCL. In agreement, MK-8628/OTX015 has been demonstrated to alter the MYC and E2F1-dependent gene expression signature by downregulating the expression of signaling proteins belonging to the NF- $\kappa \mathrm{B}$, Toll-like receptor (TLR), and Janus kinase/signal transducers and activators of transcription (JAK/STAT) pathways, including IRAK1, TLR6, TNFRSF17, MYD88, IRAK1, IL6, and IRF4 [76]. Additionally, ATAC-Seq analysis performed with the SET-2 AML cell line treated with this compound revealed its capacity to impair the chromatin accessibility of transcription initiation complexes at genome wide level [77].

The dihydroquinazolinone PFI-1 (PF-6405761), initially designed as a BET chemical probe, exhibited activity against leukemic cell lines carrying $M L L$ rearrangements by impairing their clonogenic growth upon cell cycle arrest at the $G_{1}$ phase and inducing apoptosis, with a concomitant decrease in the expression of MYC and one of its target genes, $A U R K B$, which promoted a global reduction in Histone $\mathrm{H} 3$ phosphorylation at Ser10 [78].

Similarly to PFI-1, the benzodiazepine I-BET762 also binds the BRD2 and BRD4 acetyl-lysine binding pockets and prevents their interaction with the acetylated histone tails. This molecule has shown remarkable apoptogenic activity in human and mouse lymphoma cells, mediated by a p53-independent and BCL-2 family-dependent activation of the intrinsic mitochondrial apoptotic pathway [79].

Among the BET inhibitors with prominent pro-apoptotic activity, the BRD2/BRD4-selective BETi ABBV-075 strongly triggered apoptosis in AML, NHL, and MM cell lines, and had mainly a broad antiproliferative activity across different solid tumor-derived cell lines [80]. Formulations containing ABBV-075 are currently in clinical trials for the treatment of advanced hematologic malignancies (see below).

Importantly, the pan-BET inhibitor bromosporine (BSP), with a nanomolar affinity for 13 bromodomains and low micromolar affinity for 12 additional ones (either BET or non-BET BRDs-containing proteins), has been developed to determine the role of BET proteins in leukemic cell lines. BSP showed similar effects to JQ1 towards the modulation of cell proliferation and clonogenic growth, whereas it did not show almost any of the characterized gene expression effects 
when specifically inhibiting non-BET proteins, thus indicating that only BET proteins (and not other BRDs-containing factors) have a predominant role in leukemogenesis [81].

Recently, a novel BETi named INCB054329 has been evaluated both in preclinical and phase I clinical trials. The chemical structure of this compound was designed to promote its interaction with both BRD4 BD1 acetyl lysine binding pockets and tryptophan-proline-phenylalanine (WPF) shelf. In preclinical works, INCB054329 demonstrated significant antiproliferative effects over 32 cell lines derived from hematological malignancies including AML, NHLs, and MMs, as well as a significant reduction of tumor growth for OPM-2 myeloma cell lines xenografted in mice. In particular for myeloma cells, INCB054329 also evidenced pro-apoptotic properties. Both antiproliferative and pro-apoptotic effects were driven by a mechanism involving BRD4 displacement from MYC, FGFR3, IL6R, and NSD2 enhancers, with a concomitant reduction in the corresponding mRNA levels and an increase in myeloma cells sensitivity to JAK inhibitors, thus arising the possibility of obtaining therapeutic advantages from the combination of these two kind of compounds [82]. The mechanisms of action of BET inhibitors are summarized in Figure 2.

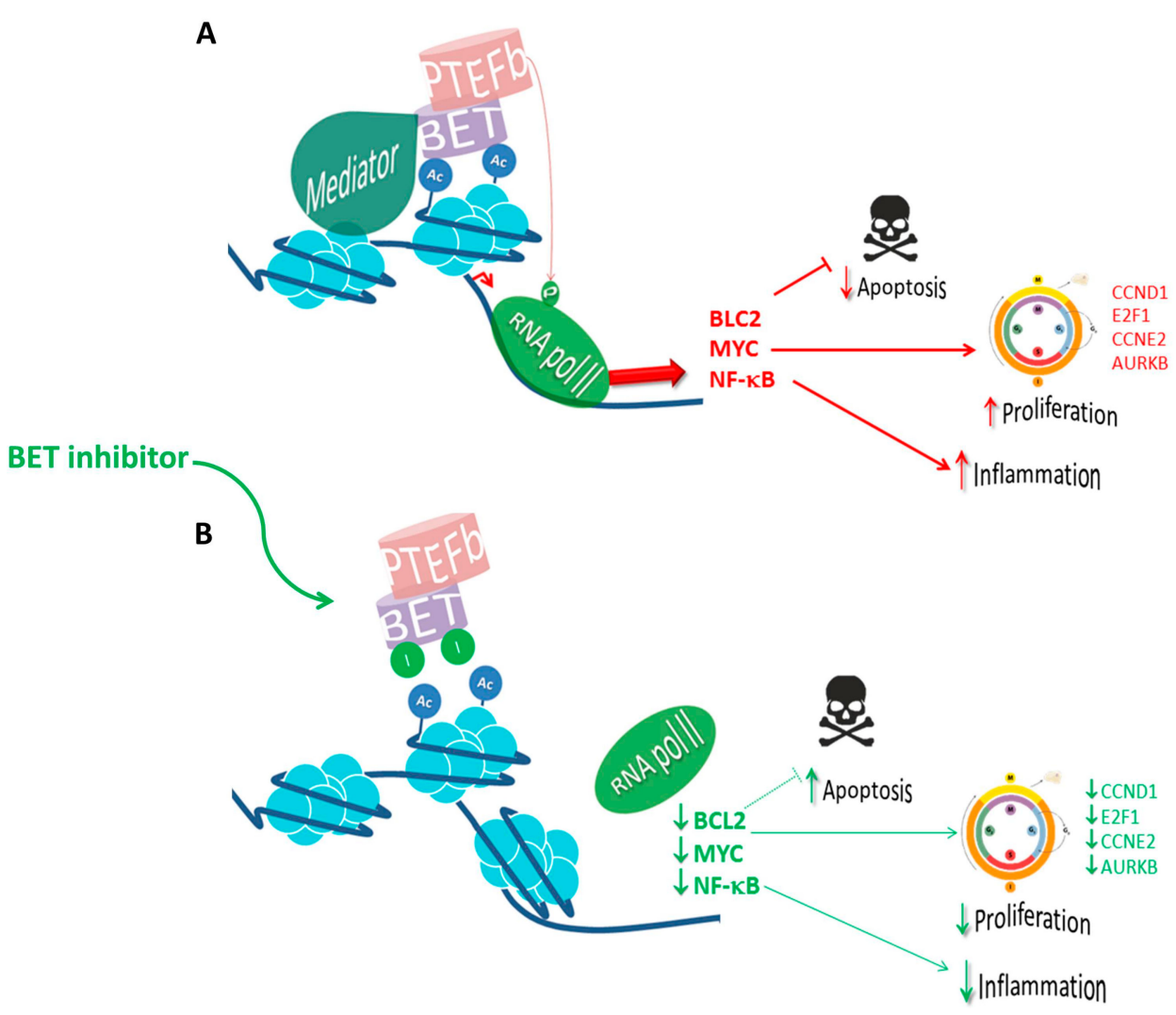

Figure 2. The mechanism of action of BET inhibitors in the clinics. (A) BET proteins regulate the transcription of genes related to multiple functions, including cell cycle, proliferation, and inflammation. The BET family member BRD4 has an important role in keeping oncogenic expression of MYC in hematopoietic malignancies. In addition, BRD4 also regulates BCL-2 leading to a decrease in apoptosis. Furthermore, it induces cell proliferation by upregulating $(\uparrow)$ CCND1, E2F1, CCNE2, and AURKB and is responsible for the transcriptional activation of NF- $\mathrm{KB}$ inflammatory response. (B) BET inhibitors compete with acetylated residues releasing BRDs from chromatin, reducing RNA-Pol II blocking $(\downarrow)$ transcription of downstream genes. The red arrows $(\rightarrow)$ indicate the oncogenic pathways mediated by $\mathrm{BET}$, the green arrows $(\rightarrow)$ highlight the effect of BET inhibitors. 


\subsection{Evaluation of BET Inhibitors as Part of Combination Therapies in Preclinical Settings}

Given their high activity against a number of signaling pathways crucial for the promotion of lymphoid tumors, BET inhibitors have also been evaluated in numerous combination trials in different subtypes of hematological malignancies.

Among the tested inhibitors, JQ1 was used in vitro and in mouse xenografts of activated B-cell (ABC) DLBCL subtypes in combination with ibrutinib, the first-in-class inhibitor of Bruton's kinase (BTK). The rationale behind the simultaneous use of those agents relies on the fact that both BCR and BRD2/BRD4 activity promote the activation of IKK, an apical kinase of the NF- $K B$ pathway known to be over-activated in ABC-DLBCL. Accordingly, JQ1 has been demonstrated to potentiate ibrutinib activity in both in vitro and in vivo models of ABC-DLBCL, mediated by synergistic inhibition of NF-kB-driven signaling [68].

Synergistic antiproliferative effects were also observed with OTX015 when tested over a panel of five DLBCL cell lines in combination with either mTOR, PI3K-delta, or BTK inhibitors (everolimus, idelalisib, and ibutrinib respectively), immunomodulatory drugs (IMiDs, lenanidomide), DNA methyltransferase inhibitor (decitabine), chemotherapy agents (doxorubicin and bendamustine), or the anti-CD20 targeting antibody rituximab [76]. In line with those findings, antitumoral effects have also been described for OTX015 when assessed over SUDHL-2-derived mouse xenografts in combination with different biological agents including the HDACi vorinostat, everolimus, rituximab, or ibutrinib [83].

Considering the role of MYC oncogenic translocation described in BL and [84,85], many efforts have been put in the identification of synergic combinations between different BET inhibitors and other biological agents. In this direction, Tomska et al. reported the results of a high throughput combinatorial screening of different inhibitory compounds, and their effect on the cell viability of 32 different blood cancer cell lines, including 17 BL lines. Despite the high heterogenic results attributed to the large subset of cell lines, the authors pointed out the strong synergistic effects of OTX015 in combination with the CDK2/7/9 inhibitor SNS-032 and the PI3K/AKT/mTOR pathway inhibitors idelalisib, duvelisib, MK-2206, everolimus, and deforolimus [86].

Other combinatorial treatments assessed in preclinical settings included JQ1, CPI0610, ABBV-075, MK-8628/OTX015, and I-BET762 in association with and the HDAC inhibitors vorinostat and romidepsin, or the BCL-2 inhibitor venetoclax, in preclinical models of cutaneous T-cell lymphoma (CTCL) including patient-derived primary samples and CTCL cell lines [87]. The rationale behind these different combinations relied (i) on the fact that, whereas HDACs regulate acetylation levels of DNA-associated proteins [88], BET proteins bind acetylated histones, promoting initiation of transcription and (ii) on the demonstration that transcription of the BCL2 gene was impaired upon BET protein inhibition [89-91]. Accordingly, authors observed additive effects in the inhibition of the cell cycle regulators MYC, NF-kB, cyclin D1, and IL5R $\alpha$ in the promotion of the expression of the negative cell cycle regulator $\mathrm{CDKN1A}$, and in the induction of some death receptor/ligand family members (TRAIL, FasL, DS4, DS5 and TNFR1) upon simultaneous exposure of human CTCL cell lines to BET inhibitors and HDAC inhibitors [92].

The BETi ABBV-075 has been evaluated as a putative agent to overcome resistances to venetoclax-mediated BCL-2 inhibition in both AML cell lines as well as in models of AML blast progenitor cells (BPCs) engrafted in immune-compromised mice. The rationale underlying the efficacy of this combination was that single agent treatment with venetoclax induced the expression of the anti-apoptotic MCL-1 as a compensatory mechanism, whereas ABBV-075 was able to remarkably block the transcription of this BRD4-controlled gene [93].

Following the previous attempts to combine BET inhibitors and epigenetic drugs, other combinations, including the BETi RVX2135 and the HDAC inhibitors vorinostat or LBH-589, have also been assessed in MYC-induced murine lymphoma cells, showing a synergistic pro-apoptotic effect, which was believed to rely on BET inhibitors capacity to induce the re-expression of several HDAC-silenced genes [94]. 
Likewise, other combinatorial treatments successfully tested in preclinical trials for DLBCL include the BETi CPI203 and the CXCR4 inhibitor IQS-01.01RS. The rationale of this combination relies on the malignant cells' capacity to overexpress CXCR4, allowing them to interact with the corresponding stromal ligand, the chemokine CXL12, and to colonize the vascular and endosteal niches, increasing the probabilities of relapse after treatment with (chemo)-immunotherapy. Overactivation of the CXCR4-CXL12 axis leads also to hyperphosphorylation of ERK and AKT, and its inhibition with the CXCR4 antagonist led to a reduction in the phosphorylation levels of these proteins and to the destabilization of MYC protein. Accordingly, IQS-01.01RS and CPI203 combinatorial treatment achieved a synergistic downregulation of MYC an improved tumor growth inhibition in DLBCL cell lines and xenograft model [67]. Thanks to its capacity to modulate BCL-2 and BCL-2-like protein levels, and to block IRF4/MYC signaling, CPI203 also exerted notable activity either as single agent or in combination with the BCL-2 antagonist venetoclax in $M Y C+/ B C L 2+$ DHL [70], or combined with the proteasome inhibitor bortezomib or lenalidomide in bortezomib-resistant MCL [66].

Of special interest, a combination of CPI0610 with the IMiDs lenalidomide and pomalidomide showed also in vitro synergism, involving the inhibition of the IKZF1/IRF4/MYC signaling axis [72] and warranting the clinical evaluation of this combination strategy in MM patients.

Similarly JQ-1, IBET151 and PFI-1 have also been shown to synergistically interact with the IMiDs in in vitro and in vivo models of primary effusion lymphoma (PEL) [95].

With regard to the INCB054329 inhibitor and its potential to downregulate IL6R expression and sensitize myeloma cells to JAK2 inhibitors, preclinical studies combining this compound with inhibitors of the JAK-STAT pathway such as ruxolitinib or itacitinib demonstrated synergistic effects and enhanced efficiency in reducing myeloma cell proliferation and MM tumor growth [82].

Of note, in almost all the above-cited experimental studies, it has been suggested that beside the cytostatic activity of the different BET inhibitors when used as single agents, additive and/or synergistic effects with drugs targeting distinct regulatory proteins underlined an enhanced cytotoxicity and/or capacity to overcome resistances to standard or experimental agents, thus warranting their evaluation in clinical settings in the majority of cases [96].

\section{Targeting BET in Hematological Cancer Patients}

The safety, tolerability, pharmacokinetics, pharmacodynamics, and clinical activity of BET inhibitors have been extensively tested in clinical trials for distinct cancers, including hematological malignancies (Table 1). The OTX015 compound was the first one that underwent clinical trials for the treatment of AML. Although no correlation was found between the degree of response and the presence of somatic mutations in 42 genes related to AML including NPM1, IDH2, FLT3, EV11, and KMT2A, preliminary activity was observed in five of the total 41 enrolled patients (NCT01713582) [97]. OTX015 was also evaluated in a cohort of 45 patients with lymphoma $(n=33)$ and MM $(n=12)$, with three DLBCL patients achieving complete remission lasting between 4 and 13 months, although no association between MYC expression levels and OTX015 sensitivity could be identified (NCT01713582) [97]. Regarding treatment-related toxicity, although the authors showed that thrombocytopenia is an early adverse event during OTX015 treatment, this condition was manageable at a dose of $80 \mathrm{mg}$, once a day on 14 days-on 7 days-off schedule. Moreover, doses above this level were associated with increased toxicity without a clear effect on efficacy. The most common nonhematological toxicities observed were gastrointestinal and cutaneous events, fatigue, metabolic disorders, and hyperglycaemia [97]. The reported adverse effects for each BET inhibitor tested in clinical trials are summarized in Table 2. 
Table 1. Ongoing clinical trials evaluating BET inhibitors in hematological cancers.

\begin{tabular}{cccccc}
\hline BET Inhibitor & Target & $\begin{array}{c}\text { Drug } \\
\text { Combination }\end{array}$ & Disease & $\begin{array}{c}\text { Study Phase } \\
\text { (Number) }\end{array}$ & Status \\
\hline GSK525762/C & BRD2/3/4 & - & MM & I (NCT01587703) & $\begin{array}{c}\text { Active, not } \\
\text { recruiting }\end{array}$ \\
\hline OTX015/MK-8628 & & $\begin{array}{c}\text { Entinostat, } \\
\text { Molibresib }\end{array}$ & Lymphomas & I (NCT03925428) & $\begin{array}{c}\text { Not yet } \\
\text { recruiting }\end{array}$ \\
\hline CC-90010 & BDR2 & - & AML, MDS, DLBCL & I (NCT02698189) & $\begin{array}{c}\text { Active, not } \\
\text { recruiting }\end{array}$ \\
\hline CPI0610 & BRD4 & Ruxolitinib & AML, MDS & II (NCT02158858) & Recruiting \\
\hline ABBV-744 & - & AML & I (NCT03360006) & Recruiting \\
\hline BI 894999 & & - & DLBCL & I (NCT02516553) & Recruiting \\
\hline BMS-986158 & & Lymphoma & I (NCT03936465) & Recruiting \\
\hline RO6870810 & Daratumumab & MM & I (NCT03068351) & $\begin{array}{c}\text { Active, not } \\
\text { recruiting }\end{array}$ \\
\hline & Venetoclax, & $\begin{array}{c}\text { R/R-DLBCL, } \\
\text { Righ-grade B-cell } \\
\text { lymphoma }\end{array}$ & I (NCT03255096) & $\begin{array}{c}\text { Active, not } \\
\text { recruiting }\end{array}$ \\
\hline
\end{tabular}

Abbreviations: Acute lymphoblastic leukemia (ALL), Acute myeloid leukemia (AML), Burkitt lymphoma (BL), Diffuse large B-cell lymphoma (DLBCL), Multiple myeloma (MM), Myelodysplastic syndromes (MDS), Non-Hodgkin lymphoma (NHL).

Further clinical trials were also carried out with either OTX015 or INCB054329, including an interventional dose exploration study with OTX015 involving AML and DLBCL patients, or an open-label dose-escalation study with INCB054329 for the treatment of advanced solid tumors and hematologic malignancies. Unfortunately, whereas the first one had to be discontinued due to limited efficacy, the second one was withdrawn due to the high pharmacokinetics (PK) variability associated to the compound (NCT02698189, NCT02431260) [98].

Regarding CPI0610, a number of clinical trials have been launched for the treatment of certain hematological malignancies including MM (NCT02157636), AML, myelodysplasic/myeloproliferative syndrome (NCT02158858), myelofibrosis [99], and progressive ABC-DLBCL (NCT01949883). Data emerging from these clinical trials indicates that CPI0610 is well tolerated and has activity mainly in patients with relapsed/refractory lymphoma [100]. Given the role of BET proteins in the control of different processes associated to myeloproliferative disorders such as production of inflammatory cytokine, platelet counts, spleen volume, or bone marrow fibrosis [74], CPI0610 is also currently being evaluated in a phase II study as a monotherapy and in combination with the JAK2 inhibitor ruxolitinib in patients with myelofibrosis who are not eligible to receive a JAK inhibitor or have had an inadequate response to ruxolitinib [75].

GS-5829 is another BET currently being evaluated in clinical for its efficiency and tolerability to treat advanced solid tumors and hematological cancers, thanks to the demonstration of its safety profile and efficacy in rodents (NCT02392611).

As discussed above, BET inhibitors have been successfully used in combination in experimental studies, showing synergistic effects when combined with other anticancer drugs. These data suggest that rather than monotherapy, the use of BETi-based combinational therapy with other antitumoral agents might play an important role in the future. Indeed, there are several ongoing clinical trials currently evaluating BET inhibitors in combination with azacitidine, daratumumab, entinostat, exemestane, fulvestrant, molibresib, rituximab, ruxolitinib, and venetoclax for the treatment of hematological malignancies (Tables 1 and 2). 
Table 2. Efficacy and toxicity of BET inhibitors in patients with hematological cancers.

\begin{tabular}{|c|c|c|c|c|c|}
\hline BETi & Drug Combination & Target Disease and Criteria of Inclusion & $\begin{array}{l}\text { Clinical Trial (Number of } \\
\text { Patients, Age) }\end{array}$ & Response & Adverse Effects \\
\hline ABBV-075 & Venetoclax & AML, MM & $\begin{array}{c}\text { NCT02391480 } \\
(n=128, \geq 18 \text { years old })\end{array}$ & No data available & No data available \\
\hline FT-1101 & Azacitidine & $\begin{array}{c}\text { R/R AML (FLT3-ITD or FLT3-TKD mutated) } \\
\text { MDS (eligible to receive azacitidine), } \\
\text { R/R NHL (primary mediastinal, DLBCL and B-cell lymphoma) }\end{array}$ & $\begin{array}{c}\text { NCT02543879 } \\
(n=94, \geq 18 \text { years old })\end{array}$ & No data available & No data available \\
\hline \multirow[t]{2}{*}{ OTX015/MK-8628 } & - & $\begin{array}{c}\text { AML } \\
\text { Ph + ALL } \\
\text { MM (exposed to at least one } \\
\text { alkylating agent/corticosteroid/IMiD and bortezomib) } \\
\text { DLBCL }(\geq 1 \text { nonirradiated tumor } \\
\text { mass } \geq 750 \mathrm{~mm}^{3} \text { ). }\end{array}$ & $\begin{array}{c}\text { NCT01713582 } \\
(n=141, \geq 18 \text { years old })\end{array}$ & $\begin{array}{l}\text { DOR in } 6,6 \% \text { of DLBCL patients } \\
\text { and clinical activity without ORC } \\
\text { in } 13,3 \% \text { patients }\end{array}$ & $\begin{array}{l}\text { Serious adverse effects: Thrombocytopenia, febrile } \\
\text { neutropenia, leukocytosis, sinus bradycardia, } \\
\text { gastrointestinal events (grade 1-2), fatigue, asthenia } \\
\text { (grade 1-2) and infections }\end{array}$ \\
\hline & Azacitidine & AML & NCT02303782 ${ }^{+}$ & No data available & No data available \\
\hline \multirow[t]{2}{*}{ CPI0610 } & - & MM (progressed after at least one line of standard therapy) & $\begin{array}{c}\text { NCT02157636 } \\
(n=30, \geq 18 \text { years old })\end{array}$ & No data available & No data available \\
\hline & - & $\begin{array}{l}\text { Lymphoma (progressed after/prior treatment and without } \\
\text { available/effective standard therapy) }\end{array}$ & $\begin{array}{c}\text { NCT01949883 } \\
(n=64, \geq 18 \text { years old })\end{array}$ & No data available & No data available \\
\hline PLX51107 & - & R/R AML or NHL (life expectancy $\geq 3$ months) & $\begin{array}{c}\text { NCT02683395 } \\
(n=50, \geq 18 \text { years old })\end{array}$ & No data available & No data available \\
\hline BAY1238097 & - & $\begin{array}{l}\text { MM (refractory to standard treatment or with no standard therapy } \\
\text { available, life expectancy } \geq 3 \text { months) }\end{array}$ & $\begin{array}{c}\text { NCT02369029 } \\
(n=8, \geq 18 \text { years old })\end{array}$ & No data available & No data available \\
\hline GS-5829 & Exemestane, Fulvestrant & $\begin{array}{l}\text { DLBCL, PTCL (refractory to or intolerant of standard therapy or } \\
\text { no standard therapy available) }\end{array}$ & $\begin{array}{c}\text { NCT02392611 } \\
(n=33, \geq 18 \text { years old })\end{array}$ & No data available & No data available \\
\hline INCB054329 & - & $\begin{array}{l}\text { DLBCL, AML, MM, ALL, BL (progressed following at least } 1 \text { line } \\
\text { of therapy without further approved therapy available) }\end{array}$ & $\begin{array}{c}\text { NCT02431260 } \\
(n=69, \geq 18 \text { years old })\end{array}$ & PK variations among individuals & $\begin{array}{c}\text { Serious adverse effects } \\
\text { Anemia, neutropenia, thrombocytopenia, } \\
\text { gastrointestinal disorders, fatigue, } \\
\text { hyperbilirubinemia, pneumonia, multi-organ failure, } \\
\text { hepatic vein thrombosis, infections increased alanine } \\
\text { and aspartate aminotransferases, hyperbilinubinemia, } \\
\text { respiratory, thoracic, and mediastinal disorders }\end{array}$ \\
\hline RO6870810 & - & $\begin{array}{l}\text { R/R AML and MDS (allogeneic stem cell transplant not treated } \\
\text { with immunosuppressors for } \geq 2 \text { weeks, life expectancy } \geq 2 \text { months) }\end{array}$ & $\begin{array}{c}\text { NCT02308761 } \\
(n=26, \geq 18 \text { years old })\end{array}$ & No data available & No data available \\
\hline
\end{tabular}

Abbreviations: Acute lymphoblastic leukemia (ALL), Acute myeloid leukemia (AML), Burkitt lymphoma (BL), Diffuse large B-cell lymphoma (DLBCL), Multiple myeloma (MM),

Myelodysplastic syndrome (MDS), Non-Hodgkin lymphoma (NHL), Relapsed/Refractory (R/R), Durable Objective Response (DOR), Objective Response Criteria (ORC). ${ }^{\dagger}$ Withdrawn ${ }^{+\dagger}$

Terminated. Philadelphia chromosome positive (Ph+), Immunomodulatory drug (IMiD). 


\section{Mechanisms of Resistance to BET Inhibitors}

As previously mentioned, constitutive activation of the BRD4-MYC axis is a general hallmark of hematological disorders, and in these models the use of BET inhibitors circumvents the MYC transcriptional program, leading to a consistent antitumor effect [49]. Although initial results generated from both preclinical and clinical evaluation of the different BET inhibitors are in general promising, the antitumoral capacity varies greatly among these agents [42]. Furthermore, recent research has shown that cancer cells can acquire resistance to this class of drug after prolonged treatment. To date, the described mechanisms of acquired resistance to BET inhibitors have not been related to the acquisition of somatic mutations or changes in copy number of the BET bromodomain genes, but rather to secondary adaptation consisting on compensatory changes in the activation of mechanisms that regulate the initiation and elongation of transcription. Some works have reported these kind of adaptive response in AML cells, in which the acquisition of resistance to BET inhibitors has been linked to a downmodulation of BRD4 protein and activation of the NF- $\mathrm{KB}$ pathway without altering the expression levels of MYC, coinciding with an aberrant activation of the $\mathrm{WNT} / \beta$-catenin and the TGF- $\beta$ signaling pathways [101].

A mechanism of resistance to BET inhibitors in AML cells suggested by Rather et al. consists of the acquisition of BRD4 independence to drive MYC transcription trough the suppression of PRC2 complex activity [102]. Other works carried out in triple negative breast cancer cells (TNBCs) have shown the acquisition of resistance to be associated with the hyperphosphorylation state of BRD4 as a consequence of a reduction in the expression of the BRD4 phosphatase, PP2A, and a concomitant enrichment in the levels of the transcriptional activator associated with BRD4, MED1 [103].

Another mechanism of escape to BET inhibitor's activity is a defective intrinsic mitochondrial cell death, as described in the $E \mu$-myc transgenic mouse model and in human B-cell lymphoma samples. In this work, short-term resistance to I-BET762 is attributed to the deletion of apoptotic peptidase initiating factor-1 (APAF-1), a key transducer of the apoptotic cascade elicited by mitochondrial apoptogenic factors. Nevertheless, this resistance can be overcome after a compensatory mechanism involving the induction of autophagy as suggested by an increase in the active form of LC3, a hallmark of autophagy, when depleting the cells from APAF-1. Interestingly, long-term resistance to I-BET762-mediated apoptosis had been described as a result of induction of anti-apoptotic BCL-2 [79].

\section{Future Generations of Bromodomain Inhibitors}

Over recent years, a different and novel approach to target BETs has been developed in order to inhibit this family of proteins, through specific BET degradation mediated by the use of Proteolysis-Targeting Chimaeras (PROTACs). To date, this approach has been only used to target the BRD4 protein. Functionally these molecules arise from the fusion between a hetero-bifunctional synthetic ligand composed of the corresponding targeted BET bromodomain's ligand (which functions as a PROTAC anchor), and the von Hippel-Lindau (VHL) E3 ubiquitin ligase, which triggers BET protein ubiquitination and further proteasome-mediated degradation $[104,105]$. According to the BRD's selectivity, three BET-PROTACs have been developed to date that can target both BRD2 and BRD4 degradation-dBET1, ARV-825, and MZ1, this latest being the one with the highest potency [106]. As a functional validation, these molecules efficiently induced apoptosis in MCL-derived cells resistant to ibrutinib, and allowed prolonged survival of MCL xenografts, an effect that was superior to that observed in OTX015-treated animals [107]. On the other hand, dBET1 was shown to evoke a rapid degradation of BRD4, followed by the blockade of MYC transcription, and induction of apoptosis in AML cell lines and primary cultures, as well as in an AML xenograft model [108]. Based on a similar synthetic scheme, the optimized small-molecule degrader ABET6 allowed extending observations on bromodomain-independent functions in T-ALL. In this model, acute loss of BRD4 elicited a global disruption of productive transcription elongation and a collapse of the core regulatory circuitry, more resembling CDK9 inhibition than BET bromodomain displacement, and thus redefining the role of BRD4 in global gene regulation [109]. 
Another facet of BRD4 that has been exploited for therapeutic purposes is its atypical kinase activity [110], which led to the screening of a panel of kinase inhibitors with the ability to bind Ac-K binding pockets of BRD4. This study led to the identification of PLK1- and JAK2-interfering drugs as potent and selective inhibitors of BRD4-BET kinase activity [111]. Although promising results have been reported for this new generation of BET-targeting agents in preclinical trials, their therapeutic window when moving to clinical trials has still to be evaluated.

\section{Conclusions}

BET protein inhibitors are the first example of a successful pharmacological blockade of epigenetic readers, and are a large and diverse group of epigenetic regulators that recently gained interest in several hematological cancers. Unlike previous epigenetic drugs, an in-depth mechanistic characterization preceded the clinical evaluation of this new class of agents in different settings, including refractory AML, MM, and aggressive B-cell lymphoma. The first reports of clinical activity in these highly treated patients with acceptable off-target effects are supporting further progress to phase II trials. Along with the insights into the alterations of bromodomain-containing proteins in the biology of hematologic malignancies, the realm of drug discovery in this field is expanding fast, with emerging new concepts and technologies for targeted molecular drug development. Newer approaches including BET protein degradation and BET-kinase inhibitors are now changing the landscape of available targeted therapies. Future research regarding these new classes of agent will include the identification of biomarkers and the evaluation of different kinds of combination therapies.

Author Contributions: D.R.-G., M.L.R. and G.R. contributed to the conception and design of the Review. All authors wrote the manuscript, contributed to the revision, and approved the submitted version.

Funding: G.R. acknowledges supports from Fondo de Investigación Sanitaria PI15/00102 and PI18/01383, European Regional Development Fund (ERDF) “Una manera de hacer Europa”.

Conflicts of Interest: G.R. received research support from TG Therapeutics and Celgene Corp. Remaining authors declare no competing interests.

\section{References}

1. Roth, S.Y.; Denu, J.M.; Allis, C.D. Histone Acetyltransferases. Annu. Rev. Biochem. 2001. [CrossRef]

2. Filippakopoulos, P.; Knapp, S. Targeting bromodomains: Epigenetic readers of lysine acetylation. Nat. Rev. Drug Discov. 2014, 13, 337-356. [CrossRef]

3. Barneda-Zahonero, B.; Parra, M. Histone deacetylases and cancer. Mol. Oncol. 2012. [CrossRef]

4. Dhalluin, C.; Carlson, J.E.; Zeng, L.; He, C.; Aggarwal, A.K.; Zhou, M.M. Structure and ligand of a histone acetyltransferase bromodomain. Nature 1999. [CrossRef]

5. Seto, E.; Yoshida, M. Erasers of histone acetylation: The histone deacetylase enzymes. Cold Spring Harb. Perspect. Biol. 2014. [CrossRef]

6. Chen, Y.; Fu, L.L.; Wen, X.; Wang, X.Y.; Liu, J.; Cheng, Y.; Huang, J. Sirtuin-3 (SIRT3), a therapeutic target with oncogenic and tumor-suppressive function in cancer. Cell Death Dis. 2014. [CrossRef]

7. Gillette, T.G.; Hill, J.A. Readers, writers, and erasers: Chromatin as the whiteboard of heart disease. Circ. Res. 2015. [CrossRef]

8. Filippakopoulos, P.; Picaud, S.; Mangos, M.; Keates, T.; Lambert, J.-P.; Barsyte-Lovejoy, D.; Felletar, I.; Volkmer, R.; Müller, S.; Pawson, T.; et al. Histone recognition and large-scale structural analysis of the human bromodomain family. Cell 2012, 149, 214-231. [CrossRef]

9. Basheer, F.; Huntly, B.J.P. BET bromodomain inhibitors in leukemia. Exp. Hematol. 2015, 43, 718-731. [CrossRef]

10. Denis, G.V.; Vaziri, C.; Guo, N.; Faller, D. V RING3 kinase transactivates promoters of cell cycle regulatory genes through E2F. Cell Growth Differ. 2000. [CrossRef]

11. Ostrowski, J.; Florio, S.K.; Denis, G.V.; Suzuki, H.; Bomsztyk, K. Stimulation of p85/RING3 kinase in multiple organs after systemic administration of mitogens into mice. Oncogene 1998. [CrossRef] [PubMed] 
12. Huang, H.; Zhang, J.; Shen, W.; Wang, X.; Wu, J.; Wu, J.; Shi, Y. Solution structure of the second bromodomain of Brd2 and its specific interaction with acetylated histone tails. BMC Struct. Biol. 2007. [CrossRef] [PubMed]

13. Nakamura, Y.; Umehara, T.; Nakano, K.; Moon, K.J.; Shirouzu, M.; Morita, S.; Uda-Tochio, H.; Hamana, H.; Terada, T.; Adachi, N.; et al. Crystal structure of the human BRD2 bromodomain: Insights into dimerization and recognition of acetylated histone H4. J. Biol. Chem. 2007. [CrossRef] [PubMed]

14. Denis, G.V.; McComb, M.E.; Faller, D.V.; Sinha, A.; Romesser, P.B.; Costello, C.E. Identification of transcription complexes that contain the double bromodomain protein $\mathrm{Brd} 2$ and chromatin remodeling machines. J. Proteome Res. 2006. [CrossRef] [PubMed]

15. LeRoy, G.; Rickards, B.; Flint, S.J. The Double Bromodomain Proteins Brd2 and Brd3 Couple Histone Acetylation to Transcription. Mol. Cell 2008. [CrossRef]

16. SINHA, A.; FALLER, D.V.; DENIS, G.V. Bromodomain analysis of Brd2-dependent transcriptional activation of cyclin A 1. Biochem. J. 2005. [CrossRef]

17. Wu, S.Y.; Chiang, C.M. The double bromodomain-containing chromatin adaptor Brd4 and transcriptional regulation. J. Biol. Chem. 2007. [CrossRef]

18. Jiang, Y.W.; Veschambre, P.; Erdjument-Bromage, H.; Tempst, P.; Conaway, J.W.; Conaway, R.C.; Kornberg, R.D. Mammalian mediator of transcriptional regulation and its possible role as an end-point of signal transduction pathways. Proc. Natl. Acad. Sci. USA 1998. [CrossRef]

19. Moon, K.J.; Mochizuki, K.; Zhou, M.; Jeong, H.S.; Brady, J.N.; Ozato, K. The bromodomain protein Brd4 is a positive regulatory component of $\mathrm{P}-\mathrm{TEFb}$ and stimulates RNA polymerase II-dependent transcription. Mol. Cell 2005. [CrossRef]

20. Donner, A.J.; Ebmeier, C.C.; Taatjes, D.J.; Espinosa, J.M. CDK8 is a positive regulator of transcriptional elongation within the serum response network. Nat. Struct. Mol. Biol. 2010. [CrossRef]

21. Bhagwat, A.S.; Roe, J.S.; Mok, B.Y.L.; Hohmann, A.F.; Shi, J.; Vakoc, C.R. BET Bromodomain Inhibition Releases the Mediator Complex from Select cis-Regulatory Elements. Cell Rep. 2016. [CrossRef] [PubMed]

22. Dey, A.; Ellenberg, J.; Farina, A.; Coleman, A.E.; Maruyama, T.; Sciortino, S.; Lippincott-Schwartz, J.; Ozato, K. A Bromodomain Protein, MCAP, Associates with Mitotic Chromosomes and Affects G2-to-M Transition. Mol. Cell. Biol. 2002. [CrossRef] [PubMed]

23. Mochizuki, K.; Nishiyama, A.; Moon, K.J.; Dey, A.; Ghosh, A.; Tamura, T.; Natsume, H.; Yao, H.; Ozato, K. The bromodomain protein Brd4 stimulates g1 gene transcription and promotes progression to $\mathrm{S}$ phase. J. Biol. Chem. 2008. [CrossRef] [PubMed]

24. Yang, Z.; He, N.; Zhou, Q. Brd4 Recruits P-TEFb to Chromosomes at Late Mitosis To Promote G1 Gene Expression and Cell Cycle Progression. Mol. Cell. Biol. 2008. [CrossRef] [PubMed]

25. Rahl, P.B.; Lin, C.Y.; Seila, A.C.; Flynn, R.A.; McCuine, S.; Burge, C.B.; Sharp, P.A.; Young, R.A. C-Myc regulates transcriptional pause release. Cell 2010. [CrossRef] [PubMed]

26. Schröder, S.; Cho, S.; Zeng, L.; Zhang, Q.; Kaehlcke, K.; Mak, L.; Lau, J.; Bisgrove, D.; Schnölzer, M.; Verdin, E.; et al. Two-pronged binding with bromodomain-containing protein 4 liberates positive transcription elongation factor $\mathrm{b}$ from inactive ribonucleoprotein complexes. J. Biol. Chem. 2012. [CrossRef]

27. Roe, J.S.; Mercan, F.; Rivera, K.; Pappin, D.J.; Vakoc, C.R. BET Bromodomain Inhibition Suppresses the Function of Hematopoietic Transcription Factors in Acute Myeloid Leukemia. Mol. Cell 2015. [CrossRef]

28. Stonestrom, A.J.; Hsu, S.C.; Jahn, K.S.; Huang, P.; Keller, C.A.; Giardine, B.M.; Kadauke, S.; Campbell, A.E.; Evans, P.; Hardison, R.C.; et al. Functions of BET proteins in erythroid gene expression. Blood 2015. [CrossRef]

29. Donati, B.; Lorenzini, E.; Ciarrocchi, A. BRD4 and Cancer: Going beyond transcriptional regulation. Mol. Cancer 2018. [CrossRef]

30. Chen, L.F.; Fischle, W.; Verdin, E.; Greene, W.C. Duration of nuclear NF- $\kappa$ B action regulated by reversible acetylation. Science 2001. [CrossRef]

31. Huang, B.; Yang, X.-D.; Zhou, M.-M.; Ozato, K.; Chen, L.-F. Brd4 Coactivates Transcriptional Activation of NF-B via Specific Binding to Acetylated RelA. Mol. Cell. Biol. 2009. [CrossRef] [PubMed]

32. Wang, R.; Li, Q.; Helfer, C.M.; Jiao, J.; You, J. Bromodomain protein Brd4 associated with acetylated chromatin is important for maintenance of higher-order chromatin structure. J. Biol. Chem. 2012. [CrossRef] [PubMed]

33. Devaiah, B.N.; Case-Borden, C.; Gegonne, A.; Hsu, C.H.; Chen, Q.; Meerzaman, D.; Dey, A.; Ozato, K.; Singer, D.S. BRD4 is a histone acetyltransferase that evicts nucleosomes from chromatin. Nat. Struct. Mol. Biol. 2016. [CrossRef] [PubMed] 
34. Stanlie, A.; Yousif, A.S.; Akiyama, H.; Honjo, T.; Begum, N.A. Chromatin reader Brd4 functions in Ig class switching as a repair complex adaptor of nonhomologous end-joining. Mol. Cell 2014. [CrossRef]

35. Li, X.; Baek, G.H.; Ramanand, S.G.; Sharp, A.; Gao, Y.; Yuan, W.; Welti, J.; Rodrigues, D.N.; Dolling, D.; Figueiredo, I.; et al. BRD4 Promotes DNA Repair and Mediates the Formation of TMPRSS2-ERG Gene Rearrangements in Prostate Cancer. Cell Rep. 2018. [CrossRef] [PubMed]

36. Zhang, J.; Dulak, A.M.; Hattersley, M.M.; Willis, B.S.; Nikkilä, J.; Wang, A.; Lau, A.; Reimer, C.; Zinda, M.; Fawell, S.E.; et al. BRD4 facilitates replication stress-induced DNA damage response. Oncogene 2018. [CrossRef]

37. Akıncılar, S.C.; Khattar, E.; Boon, P.L.S.; Unal, B.; Fullwood, M.J.; Tergaonkar, V. Long-range chromatin interactions drive mutant TERT promoter activation. Cancer Discov. 2016. [CrossRef]

38. Wang, S.; Pike, A.M.; Lee, S.S.; Strong, M.A.; Connelly, C.J.; Greider, C.W. BRD4 inhibitors block telomere elongation. Nucleic Acids Res. 2017. [CrossRef]

39. Zuber, J.; Shi, J.; Wang, E.; Rappaport, A.R.; Herrmann, H.; Sison, E.A.; Magoon, D.; Qi, J.; Blatt, K.; Wunderlich, M.; et al. RNAi screen identifies Brd4 as a therapeutic target in acute myeloid leukaemia. Nature 2011, 478, 524-528. [CrossRef]

40. Ott, C.J.; Kopp, N.; Bird, L.; Paranal, R.M.; Qi, J.; Bowman, T.; Rodig, S.J.; Kung, A.L.; Bradner, J.E.; Weinstock, D.M. BET bromodomain inhibition targets both c-Myc and IL7R in high-risk acute lymphoblastic leukemia. Blood 2012. [CrossRef]

41. Delmore, J.E.; Issa, G.C.; Lemieux, M.E.; Rahl, P.B.; Shi, J.; Jacobs, H.M.; Kastritis, E.; Gilpatrick, T.; Paranal, R.M.; Qi, J.; et al. BET bromodomain inhibition as a therapeutic strategy to target c-Myc. Cell 2011. [CrossRef] [PubMed]

42. Mertz, J.A.; Conery, A.R.; Bryant, B.M.; Sandy, P.; Balasubramanian, S.; Mele, D.A.; Bergeron, L.; Sims, R.J. Targeting MYC dependence in cancer by inhibiting BET bromodomains. Proc. Natl. Acad. Sci. USA 2011. [CrossRef] [PubMed]

43. Dang, C.V. MYC on the path to cancer. Cell 2012. [CrossRef] [PubMed]

44. Lin, C.Y.; Lovén, J.; Rahl, P.B.; Paranal, R.M.; Burge, C.B.; Bradner, J.E.; Lee, T.I.; Young, R.A. Transcriptional amplification in tumor cells with elevated c-Myc. Cell 2012. [CrossRef]

45. Frank, S.R.; Parisi, T.; Taubert, S.; Fernandez, P.; Fuchs, M.; Chan, H.M.; Livingston, D.M.; Amati, B. MYC recruits the TIP60 histone acetyltransferase complex to chromatin. EMBO Rep. 2003. [CrossRef] [PubMed]

46. Rahl, P.B.; Young, R.A. MYC and transcription elongation. Cold Spring Harb. Perspect. Med. 2014. [CrossRef]

47. Horn, H.; Ziepert, M.; Becher, C.; Barth, T.F.E.; Bernd, H.W.; Feller, A.C.; Klapper, W.; Hummel, M.; Stein, H.; Hansmann, M.L.; et al. MYC status in concert with BCL2 and BCL6 expression predicts outcome in diffuse large B-cell lymphoma. Blood 2013. [CrossRef] [PubMed]

48. Blum, K.A.; Lozanski, G.; Byrd, J.C. Adult Burkitt leukemia and lymphoma. Blood 2004. [CrossRef]

49. Lovén, J.; Hoke, H.A.; Lin, C.Y.; Lau, A.; Orlando, D.A.; Vakoc, C.R.; Bradner, J.E.; Lee, T.I.; Young, R.A. Selective inhibition of tumor oncogenes by disruption of super-enhancers. Cell 2013, 153, 320-334. [CrossRef]

50. Chapuy, B.; McKeown, M.R.; Lin, C.Y.; Monti, S.; Roemer, M.G.M.; Qi, J.; Rahl, P.B.; Sun, H.H.; Yeda, K.T.; Doench, J.G.; et al. Discovery and characterization of super-enhancer-associated dependencies in diffuse large B cell lymphoma. Cancer Cell 2013. [CrossRef]

51. Pérez-Galán, P.; Dreyling, M.; Wiestner, A. Mantle cell lymphoma: Biology, pathogenesis, and the molecular basis of treatment in the genomic era. Blood 2011. [CrossRef] [PubMed]

52. Döhner, K.; Schlenk, R.F.; Habdank, M.; Scholl, C.; Rücker, F.G.; Corbacioglu, A.; Bullinger, L.; Fröhling, S.; Döhner, H. Mutant nucleophosmin (NPM1) predicts favorable prognosis in younger adults with acute myeloid leukemia and normal cytogenetics: Interaction with other gene mutations. Blood 2005. [CrossRef] [PubMed]

53. Dawson, M.A.; Gudgin, E.J.; Horton, S.J.; Giotopoulos, G.; Meduri, E.; Robson, S.; Cannizzaro, E.; Osaki, H.; Wiese, M.; Putwain, S.; et al. Recurrent mutations, including NPM1c, activate a BRD4-dependent core transcriptional program in acute myeloid leukemia. Leukemia 2014. [CrossRef] [PubMed]

54. Falini, B.; Bolli, N.; Shan, J.; Martelli, M.P.; Liso, A.; Pucciarini, A.; Bigerna, B.; Pasqualucci, L.; Mannucci, R.; Rosati, R.; et al. Both carboxy-terminus NES motif and mutated tryptophan(s) are crucial for aberrant nuclear export of nucleophosmin leukemic mutants in NPMc+ AML. Blood 2006. [CrossRef] [PubMed]

55. Huang, M.; Zhu, L.; Garcia, J.S.; Li, M.X.; Gentles, A.J.; Mitchell, B.S. Brd4 regulates the expression of essential autophagy genes and Keap1 in AML cells. Oncotarget 2018. [CrossRef] [PubMed] 
56. Winters, A.C.; Bernt, K.M. MLL-rearranged leukemias- An update on science and clinical approaches. Front. Pediatr. 2017. [CrossRef] [PubMed]

57. Thirman, M.J.; Gill, H.J.; Burnett, R.C.; Mbangkollo, D.; McCabe, N.R.; Kobayashi, H.; Ziemin-van der Poel, S.; Kaneko, Y.; Morgan, R.; Sandberg, A.A. Rearrangement of the MLL gene in acute lymphoblastic and acute myeloid leukemias with 11q23 chromosomal translocations. N. Engl. J. Med. 1993. [CrossRef]

58. Krivtsov, A.V.; Armstrong, S.A. MLL translocations, histone modifications and leukaemia stem-cell development. Nat. Rev. Cancer 2007. [CrossRef]

59. Dawson, M.A.; Prinjha, R.K.; Dittmann, A.; Giotopoulos, G.; Bantscheff, M.; Chan, W.-I.; Robson, S.C.; Chung, C.; Hopf, C.; Savitski, M.M.; et al. Inhibition of BET recruitment to chromatin as an effective treatment for MLL-fusion leukaemia. Nature 2011, 478, 529-533. [CrossRef]

60. Resnick-Silverman, L.; Yan, S.; Mutjaba, S.; Liu, W.-J.; Zeng, L.; Manfredi, J.J.; Zhou, M.-M. Target structure-based discovery of small molecules that block human p53 and CREB binding protein association. Chem. Biol. 2006, 13, 81-90. [CrossRef]

61. Beesley, A.H.; Stirnweiss, A.; Ferrari, E.; Endersby, R.; Howlett, M.; Failes, T.W.; Arndt, G.M.; Charles, A.K.; Cole, C.H.; Kees, U.R. Comparative drug screening in NUT midline carcinoma. Br. J. Cancer 2014. [CrossRef] [PubMed]

62. Loosveld, M.; Castellano, R.; Gon, S.; Goubard, A.; Crouzet, T.; Pouyet, L.; Prebet, T.; Vey, N.; Nadel, B.; Collette, Y.; et al. Therapeutic Targeting of c-Myc in T-Cell Acute Lymphoblastic Leukemia (T-ALL). Oncotarget 2014. [CrossRef] [PubMed]

63. Filippakopoulos, P.; Qi, J.; Picaud, S.; Shen, Y.; Smith, W.B.; Fedorov, O.; Morse, E.M.; Keates, T.; Hickman, T.T.; Felletar, I.; et al. Selective inhibition of BET bromodomains. Nature 2010, 468, 1067-1073. [CrossRef] [PubMed]

64. King, B.; Trimarchi, T.; Reavie, L.; Xu, L.; Mullenders, J.; Ntziachristos, P.; Aranda-Orgilles, B.; Perez-Garcia, A.; Shi, J.; Vakoc, C.; et al. The ubiquitin ligase FBXW7 modulates leukemia-initiating cell activity by regulating MYC stability. Cell 2013, 153, 1552-1566. [CrossRef] [PubMed]

65. Normant, E.; Cummings, R.; Bellon, S.; Bailey, C.; Albrecht, B.; Hewitt, M.; Pardo, E.; Campbell, R.; Jayaram, H.; Poy, F.; et al. Abstract LB-237: In vitro and in vivo characterization of CPI-267203, a potent Inhibitor of bromodomain-containing proteins. In Proceedings of the AACR 103rd Annual Meeting, Chicago, IL, USA, 31 March-4 April 2012; Volume 72, p. LB-237-LB-237.

66. Moros, A.; Rodríguez, V.; Saborit-Villarroya, I.; Montraveta, A.; Balsas, P.; Sandy, P.; Martínez, A.; Wiestner, A.; Normant, E.; Campo, E.; et al. Synergistic antitumor activity of lenalidomide with the BET bromodomain inhibitor CPI203 in bortezomib-resistant mantle cell lymphoma. Leukemia 2014, 28, 2049-2059. [CrossRef]

67. Recasens-zorzo, C.; Cardesa-salzmann, T.; Petazzi, P.; Ros-blanco, L.; Esteve-arenys, A.; Clot, G.; Guerrero-hernández, M.; Rodríguez, V.; Soldini, D.; Valera, A.; et al. Pharmacological modulation of CXCR4 cooperates with BET bromodomain inhibition in diffuse large B-cell lymphoma. Haematologica 2018, 104, 778-788. [CrossRef] [PubMed]

68. Ceribelli, M.; Kelly, P.N.; Shaffer, A.L.; Wright, G.W.; Xiao, W.; Yang, Y.; Mathews Griner, L.A.; Guha, R.; Shinn, P.; Keller, J.M.; et al. Blockade of oncogenic IкB kinase activity in diffuse large B-cell lymphoma by bromodomain and extraterminal domain protein inhibitors. Proc. Natl. Acad. Sci. USA 2014, 111, 11365-11370. [CrossRef]

69. Siegel, M.B.; Liu, S.Q.; Davare, M.A.; Spurgeon, S.E.; Loriaux, M.M.; Druker, B.J.; Scott, E.C.; Tyner, J.W. Small molecule inhibitor screen identifies synergistic activity of the bromodomain inhibitor CPI203 and bortezomib in drug resistant myeloma. Oncotarget 2015, 6, 18921-18932. [CrossRef]

70. Esteve-Arenys, A.; Valero, J.G.; Chamorro-Jorganes, A.; Gonzalez, D.; Rodriguez, V.; Dlouhy, I.; Salaverria, I.; Campo, E.; Colomer, D.; Martinez, A.; et al. The BET bromodomain inhibitor CPI203 overcomes resistance to ABT-199 (venetoclax) by downregulation of BFL-1/A1 in in vitro and in vivo models of MYC+/BCL2+ double hit lymphoma. Oncogene 2018. [CrossRef]

71. Albrecht, B.K.; Gehling, V.S.; Hewitt, M.C.; Vaswani, R.G.; Côté, A.; Leblanc, Y.; Nasveschuk, C.G.; Bellon, S.; Bergeron, L.; Campbell, R.; et al. Identification of a Benzoisoxazoloazepine Inhibitor (CPI-0610) of the Bromodomain and Extra-Terminal (BET) Family as a Candidate for Human Clinical Trials. J. Med. Chem. 2016, 59, 1330-1339. [CrossRef] 
72. Siu, K.T.; Ramachandran, J.; Yee, A.J.; Eda, H.; Santo, L.; Panaroni, C.; Mertz, J.A.; Sims, R.J., III; Cooper, M.R.; Raje, N. Preclinical activity of CPI-0610, a novel small-molecule bromodomain and extra-terminal protein inhibitor in the therapy of multiple myeloma. Leukemia 2016, 31, 1760-1769. [CrossRef] [PubMed]

73. Zeybek, B.; Lopez, S.; Santin, A.D. BET inhibitors: Betting on improved outcomes in uterine serous carcinoma. Oncotarget 2018, 9, 35470-35471. [CrossRef] [PubMed]

74. Valero, J.G.; Chamorro-Jorganes, A.; Walker, K.; Guerrero-Hernandez, M.; Rodriguez, V.; Recasens-Zorzo, C.; Esteve-Arenys, A.; Lee-Verges, E.; Matas-Cespedes, A.; Serrat, N.; et al. The BET Inhibitor GS-626510 Converges with Idelalisib through the Inhibition of Tumor-Macrophage Crosstalk and Cytokine Production in Diffuse Large B-Cell Lymphoma. Blood 2017, 130, 4108.

75. Coudé, M.-M.; Braun, T.; Berrou, J.; Dupont, M.; Bertrand, S.; Masse, A.; Raffoux, E.; Itzykson, R.; Delord, M.; Riveiro, M.E.; et al. BET inhibitor OTX015 targets BRD2 and BRD4 and decreases c-MYC in acute leukemia cells. Oncotarget 2015. [CrossRef] [PubMed]

76. Boi, M.; Gaudio, E.; Bonetti, P.; Kwee, I.; Bernasconi, E.; Tarantelli, C.; Rinaldi, A.; Testoni, M.; Cascione, L.; Ponzoni, M.; et al. The BET bromodomain inhibitor OTX015 affects pathogenetic pathways in preclinical B-cell tumor models and synergizes with targeted drugs. Clin. Cancer Res. 2015. [CrossRef] [PubMed]

77. Sun, B.; Shah, B.; Fiskus, W.; Qi, J.; Rajapakshe, K.; Coarfa, C.; Li, L.; Devaraj, S.G.T.; Sharma, S.; Zhang, L.; et al. Synergistic activity of BET protein antagonist-based combinations in mantle cell lymphoma cells sensitive or resistant to ibrutinib. Blood 2015, 126, 1565-1574. [CrossRef]

78. Picaud, S.; Da Costa, D.; Thanasopoulou, A.; Filippakopoulos, P.; Fish, P.V.; Philpott, M.; Fedorov, O.; Brennan, P.; Bunnage, M.E.; Owen, D.R.; et al. PFI-1, a highly selective protein interaction inhibitor, targeting BET bromodomains. Cancer Res. 2013. [CrossRef] [PubMed]

79. Lasorsa, E.; Smonksey, M.; Kirk, J.S.; Rosario, S.; Hernandez-Ilizaliturri, F.J.; Ellis, L. Mitochondrial protection impairs BET bromodomain inhibitor-mediated cell death and provides rationale for combination therapeutic strategies. Cell Death Dis. 2015. [CrossRef]

80. Bui, M.H.; Lin, X.; Albert, D.H.; Li, L.; Lam, L.T.; Faivre, E.J.; Warder, S.E.; Huang, X.; Wilcox, D.; Donawho, C.K.; et al. Preclinical Characterization of BET Family Bromodomain Inhibitor ABBV-075 Suggests Combination Therapeutic Strategies. Cancer Res. 2017, 77, 2976-2989. [CrossRef] [PubMed]

81. Picaud, S.; Leonards, K.; Lambert, J.-P.; Dovey, O.; Wells, C.; Fedorov, O.; Monteiro, O.; Fujisawa, T.; Wang, C.-Y.; Lingard, H.; et al. Promiscuous targeting of bromodomains by bromosporine identifies BET proteins as master regulators of primary transcription response in leukemia. Sci. Adv. 2016. [CrossRef]

82. Stubbs, M.C.; Burn, T.C.; Sparks, R.; Maduskuie, T.; Diamond, S.; Rupar, M.; Wen, X.; Volgina, A.; Zolotarjova, N.; Waeltz, P.; et al. The Novel Bromodomain and Extraterminal Domain Inhibitor INCB054329 Induces Vulnerabilities in Myeloma Cells That Inform Rational Combination Strategies. Clin. Cancer Res. 2019, 25, 300-311. [CrossRef] [PubMed]

83. Gaudio, E.; Tarantelli, C.; Ponzoni, M.; Odore, E.; Rezai, K.; Bernasconi, E.; Cascione, L.; Rinaldi, A.; Stathis, A.; Riveiro, E.; et al. Bromodomain inhibitor OTX015 (MK-8628) combined with targeted agents shows strong in vivo antitumor activity in lymphoma. Oncotarget 2016. [CrossRef] [PubMed]

84. Dalla-Favera, R.; Bregni, M.; Erikson, J.; Patterson, D.; Gallo, R.C.; Croce, C.M. Human c-myc onc gene is located on the region of chromosome 8 that is translocated in Burkitt lymphoma cells. Proc. Natl. Acad. Sci. USA 1982. [CrossRef] [PubMed]

85. Adams, J.M.; Harris, A.W.; Pinkert, C.A.; Corcoran, L.M.; Alexander, W.S.; Cory, S.; Palmiter, R.D.; Brinster, R.L. The c-myc oncogene driven by immunoglobulin enhancers induces lymphoid malignancy in transgenic mice. Nature 1985. [CrossRef] [PubMed]

86. Tomska, K.; Kurilov, R.; Lee, K.S.; Hüllein, J.; Lukas, M.; Sellner, L.; Walther, T.; Wagner, L.; Oleś, M.; Brors, B.; et al. Drug-based perturbation screen uncovers synergistic drug combinations in Burkitt lymphoma. Sci. Rep. 2018. [CrossRef] [PubMed]

87. Kim, S.R.; Lewis, J.M.; Cyrenne, B.M.; Monico, P.F.; Mirza, F.N.; Carlson, K.R.; Foss, F.M.; Girardi, M. BET inhibition in advanced cutaneous $\mathrm{T}$ cell lymphoma is synergistically potentiated by BCL2 inhibition or HDAC inhibition. Oncotarget 2018. [CrossRef] [PubMed]

88. Choudhary, C.; Kumar, C.; Gnad, F.; Nielsen, M.L.; Rehman, M.; Walther, T.C.; Olsen, J.V.; Mann, M. Lysine acetylation targets protein complexes and co-regulates major cellular functions. Science 2009. [CrossRef] 
89. Wyce, A.; Ganji, G.; Smitheman, K.N.; Chung, C.-W.; Korenchuk, S.; Bai, Y.; Barbash, O.; Le, B.C.; Craggs, P.D.; McCabe, M.T.; et al. BET Inhibition Silences Expression of MYCN and BCL2 and Induces Cytotoxicity in Neuroblastoma Tumor Models. PLoS ONE 2013. [CrossRef]

90. Wang, H.; Hong, B.; Li, X.; Deng, K.; Li, H.; Lui, V.W.Y.; Lin, W. JQ1 synergizes with the Bcl-2 inhibitor ABT-263 against MYCN-amplified small cell lung cancer. Oncotarget 2017. [CrossRef]

91. Hogg, S.J.; Newbold, A.; Vervoort, S.J.; Cluse, L.A.; Martin, B.P.; Gregory, G.P.; Lefebure, M.; Vidacs, E.; Tothill, R.W.; Bradner, J.E.; et al. BET Inhibition Induces Apoptosis in Aggressive B-Cell Lymphoma via Epigenetic Regulation of BCL-2 Family Members. Mol. Cancer Ther. 2016, 15, 2030-2041. [CrossRef]

92. Zhao, L.; Okhovat, J.P.; Hong, E.K.; Kim, Y.H.; Wood, G.S. Preclinical Studies Support Combined Inhibition of BET Family Proteins and Histone Deacetylases as Epigenetic Therapy for Cutaneous T-Cell Lymphoma. Neoplasia (United States) 2019, 21, 82-92. [CrossRef] [PubMed]

93. Mill, C.P.; Cai, T.; Fiskus, W.; Borthakur, G.; Kornblau, S.M.; Kadia, T.M.; DiNardo, C.D.; Nowak, A.J.; Saenz, D.T.; Saenz, D.N.; et al. Mechanisms Underlying Superior Efficacy of Co-Targeting BET Proteins and Anti-Apoptotic BCL2 or MCL1 Protein Against AML Blast Progenitor Cells. Blood 2018, 132, 1351.

94. Bhadury, J.; Nilsson, L.M.; Muralidharan, S.V.; Green, L.C.; Li, Z.; Gesner, E.M.; Hansen, H.C.; Keller, U.B.; McLure, K.G.; Nilsson, J.A. BET and HDAC inhibitors induce similar genes and biological effects and synergize to kill in Myc-induced murine lymphoma. Proc. Natl. Acad. Sci. USA 2014. [CrossRef] [PubMed]

95. Gopalakrishnan, R.; Matta, H.; Tolani, B.; Triche, T., Jr.; Chaudhary, P.M. Immunomodulatory drugs target IKZF1-IRF4-MYC axis in primary effusion lymphoma in a cereblon-dependent manner and display synergistic cytotoxicity with BRD4 inhibitors. Oncogene 2015, 35, 1797-1810. [CrossRef] [PubMed]

96. Doroshow, D.B.; Eder, J.P.; LoRusso, P.M. BET inhibitors: A novel epigenetic approach. Ann. Oncol. 2017. [CrossRef]

97. Berthon, C.; Raffoux, E.; Thomas, X.; Vey, N.; Gomez-Roca, C.; Yee, K.; Taussig, D.C.; Rezai, K.; Roumier, C.; Herait, P.; et al. Bromodomain inhibitor OTX015 in patients with acute leukaemia: A dose-escalation, phase 1 study. Lancet Haematol. 2016, 3, e186-e195. [CrossRef]

98. Amorim, S.; Stathis, A.; Gleeson, M.; Iyengar, S.; Magarotto, V.; Leleu, X.; Morschhauser, F.; Karlin, L.; Broussais, F.; Rezai, K.; et al. Bromodomain inhibitor OTX015 in patients with lymphoma or multiple myeloma: A dose-escalation, open-label, pharmacokinetic, phase 1 study. Lancet Haematol. 2016, 3, e196-e204. [CrossRef]

99. Kremyanskaya, M.; Hoffman, R.; Mascarenhas, J.; Verstovsek, S.; Mertz, J.; Garner, F.; Senderowicz, A. A Phase 2 Study of Cpi-0610, a Bromodomain and Extraterminal (BET) Inhibitor, in Patients with Myelofibrosis (MF). Blood 2018, 132, 5481.

100. Abramson, J.S.; Blum, K.A.; Flinn, I.W.; Gutierrez, M.; Goy, A.; Maris, M.; Cooper, M.; O’Meara, M.; Borger, D.; Jennifer Mertz, J.; et al. BET inhibitor CPI-0610 is well tolerated and induces responses in diffuse large B-cell lymphoma and follicular lymphoma: Preliminary analysis of an ongoing phase 1 study. Blood 2015, 126, 1491.

101. Fong, C.Y.; Gilan, O.; Lam, E.Y.N.; Rubin, A.F.; Ftouni, S.; Tyler, D.; Stanley, K.; Sinha, D.; Yeh, P.; Morison, J.; et al. BET inhibitor resistance emerges from leukaemia stem cells. Nature 2015. [CrossRef]

102. Rathert, P.; Roth, M.; Neumann, T.; Muerdter, F.; Roe, J.S.; Muhar, M.; Deswal, S.; Cerny-Reiterer, S.; Peter, B.; Jude, J.; et al. Transcriptional plasticity promotes primary and acquired resistance to BET inhibition. Nature 2015. [CrossRef] [PubMed]

103. Shu, S.; Lin, C.Y.; He, H.H.; Witwicki, R.M.; Tabassum, D.P.; Roberts, J.M.; Janiszewska, M.; Huh, S.J.; Liang, Y.; Ryan, J.; et al. Response and resistance to BET bromodomain inhibitors in triple-negative breast cancer. Nature 2016. [CrossRef] [PubMed]

104. An, S.; Fu, L. Small-molecule PROTACs: An emerging and promising approach for the development of targeted therapy drugs. EBioMedicine 2018, 36, 553-562. [CrossRef] [PubMed]

105. Bondeson, D.P.; Crews, C.M. Targeted Protein Degradation by Small Molecules. Annu. Rev. Pharmacol. Toxicol. 2017. [CrossRef] [PubMed]

106. Zengerle, M.; Chan, K.H.; Ciulli, A. Selective Small Molecule Induced Degradation of the BET Bromodomain Protein BRD4. ACS Chem. Biol. 2015. [CrossRef] [PubMed]

107. Sun, B.; Fiskus, W.; Qian, Y.; Rajapakshe, K.; Raina, K.; Coleman, K.G.; Crew, A.P.; Shen, A.; Saenz, D.T.; Mill, C.P.; et al. BET protein proteolysis targeting chimera (PROTAC) exerts potent lethal activity against mantle cell lymphoma cells. Leukemia 2018, 32, 343-352. [CrossRef] 
108. Winter, G.E.; Buckley, D.L.; Paulk, J.; Roberts, J.M.; Souza, A.; Dhe-Paganon, S.; Bradner, J.E. Phthalimide conjugation as a strategy for in vivo target protein degradation. Science 2015, 348, 1376-1381. [CrossRef]

109. Winter, G.E.; Mayer, A.; Buckley, D.L.; Erb, M.A.; Roderick, J.E.; Vittori, S.; Reyes, J.M.; di Iulio, J.; Souza, A.; Ott, C.J.; et al. BET Bromodomain Proteins Function as Master Transcription Elongation Factors Independent of CDK9 Recruitment. Mol. Cell 2017, 67, 5-18.e19. [CrossRef]

110. Devaiah, B.N.; Lewis, B.A.; Cherman, N.; Hewitt, M.C.; Albrecht, B.K.; Robey, P.G.; Ozato, K.; Sims, R.J.; Singer, D.S. BRD4 is an atypical kinase that phosphorylates Serine2 of the RNA Polymerase II carboxy-terminal domain. Proc. Natl. Acad. Sci. USA 2012, 109, 6927-6932. [CrossRef]

111. Ember, S.W.J.; Zhu, J.-Y.; Olesen, S.H.; Martin, M.P.; Becker, A.; Berndt, N.; Georg, G.I.; Schönbrunn, E. Acetyl-lysine Binding Site of Bromodomain-Containing Protein 4 (BRD4) Interacts with Diverse Kinase Inhibitors. ACS Chem. Biol. 2014, 9, 1160-1171. [CrossRef]

(C) 2019 by the authors. Licensee MDPI, Basel, Switzerland. This article is an open access article distributed under the terms and conditions of the Creative Commons Attribution (CC BY) license (http://creativecommons.org/licenses/by/4.0/). 